\section{Sciensage}

Journal of Advanced Scientific Research

Available online through https: / /sciensage.info
ISSN: 0976-9595

Research Article

DOI: $10.55218 /$ JASR. 202213119

\title{
IN-VITRO ANTIMICROBIAL ACTIVITY OF ETHYL ACETATE EXTRACT OF CENTAUREA BEHEN LINN
}

\author{
Neesha Gupta*, A. Kalaiselvan \\ Sarvepalli Radhakrishnan University, Bhopal, Madhya Pradesh, India \\ *Corresponding author: Nisha.gup11@gmail.com
}

\begin{abstract}
This work aims to evaluate the antimicrobial potential of ethyl acetate extracts of Centaurea Behen Linn (C. Behen) on some microorganisms. Agar well diffusion method has been used to determine the antimicrobial activities of plant extracts against Gram-positive bacteria, Gram-negative bacteria (Streptococcus mutans, Staphylococcus aureus, Salmonella bongori and Escherichia coli), and two fungus (Candida albicans and Aspergillus niger). The extracts exhibited both antibacterial and antifungal activities against tested microorganisms using standard ofloxacin, ciprofloxacin and fluconazole (10-30 $\mu \mathrm{g} / \mathrm{ml})$. The antimicrobial activity was determined by measuring the diameter of the zone of inhibition in term of millimeter $(\mathrm{mm})$. To analyze the antimicrobial activity, ethyl acetate extract of $C$. Behen was tested by well diffusion method against six selected strain and which shows significant inhibitory action against all the tested strain. The antimicrobial activity of ethyl acetate extract of root against all microorganisms was concentration dependent but less than standard drug. It is concluded that the antimicrobial activity showed by the plant is due to the presence of phytochemicals. For future studies, phytochemcials responsible for these activities can be isolated and modified for pharmacological purpose.
\end{abstract}

Keywords: Infectious diseases, Centaurea Behen Linn, Gram-positive bacteria, Gram-negative bacteria, Antimicrobial activity.

\section{INTRODUCTION}

Antimicrobial agents are essentially important in reducing the global burden of infectious diseases [1]. However, emergence and dissemination of multidrug resistant (MDR) strain in pathogenic bacteria have become a significant public health threat as there are fewer, or even sometimes no effective antimicrobial agents available for the infection caused by pathogenic bacteria [2, 3]. Thus, in the light of the evidence of the rapid global spread of resistant clinical isolates, the need to find new antimicrobial agents is of paramount importance. However, the past record of rapid, widespread emergence of resistance to newly introduced antimicrobial agents indicates that even new families of antimicrobial agents will have a short life expectancy $[4,5]$. A vast number of medicinal plants have been recognized as valuable resources of natural antimicrobial compounds as an alternative that can potentially be effective in the treatment of these problematic bacterial infections [6]. According to the World Health Organization (WHO), medicinal plants would be the best source to obtain a variety of drugs [7]. Many plants have been used because of their antimicrobial traits, which are due to phytochemicals synthesized in the secondary metabolism of the plant $[8,9]$. Plants are rich in a wide variety of secondary metabolites such as tannins, alkaloids, phenolic compounds, and flavonoids, which have been found in vitro to have antimicrobial properties [10, 11]. A number of phytotherapy manuals have mentioned various medicinal plants for treating infectious diseases as urinary tract infections, gastrointestinal disorders, respiratory disease, and cutaneous infections. C. Behen is commonly called as White Behen, Safaid Behmen, Behman abyaz and White Rhapontic belongs to the family Asteraceae/Compositae. It is native to India, Pakistan [12], Israel, Europe, North Africa and China [13]. It is also found in Tehran, Iraq and Turkey [14], which is used as remedial agents in various diseases. C. behen has been used to treat weakness of brain, heart and liver, palpitation, hepatitis, melancholia, sexual debility, neurasthenia, spermatorrhoea, fatigue and for diseases of the stomach and intestines [15]. It is also used in jaundice and is a heart tonic [16]. The roots of $C$. behen are used for killing the lice and making the hair good smelling [17]. Roots act as nervine and anabolic tonic, strengthen central nervous system and used in 
affections of kidney [12]. Aerial parts of C. behen afforded several sesqueterpene lactones, the guaianolides cyanraopicrin, augerin B, desacylcynaropicrin, grosshemin and traces of a ketone which is closely related to solstitialin A [18]. The oil of C. behen comprises of five monoterpenes $(7.8 \%)$, eleven sesquiterpene hydrocarbons $(85.9 \%)$. Caryooyllane $(24.5 \%), \quad \beta$-selinene $(13.9 \%)$ and valencene $(11.7 \%)$ are the major components, followed by $\delta$-cadinene $(8.7 \%)$, epi- $\alpha$ muurolene (7.6\%), $\alpha$ - humulene $(6.5 \%)$ and $\alpha$-copane $(4.0 \%)$ [19]. The main constituents of the essential oil of aerial parts of $C$. behen are $\beta$-caryophyllene (40.3\%), $\beta$ sesqiphellandrene (18.4\%), and caryophene oxide (9.9\%) [20]. From the roots of C. behen, a crystalline unsaturated lactone behenin having molecular formula $\mathrm{C} 24 \mathrm{H} 48 \mathrm{O} 3$ has been obtained [21]. The roots also contain taraxasterol and its acetate, myristate, inulin and a glucoside which on hydrolysis yields centaurea sterol A [13]. Seeds contain $23 \%$ of a yellow semi-drying oil containing palmitic $(7.2 \%)$, stearic $(0.8 \%)$, oleic $(11.9 \%)$ and linoleic $(8.1 \%)$ acids. Seeds also contain the enzymes diastase, lipase and protease. Xylose and uronic acids are present in the seed oil. Lipid extract of the plant contains lupeol, stigmasterol and straight-chain hydrocarbons [13]. Considering the vast potentiality of plants as sources for antimicrobial drugs, this study aimed to investigate in vitro antibacterial and antifungal activity of ethyl acetate extracts of $C$. Behen against the most common microbial pathogens including MDR bacteria.

\section{MATERIAL AND METHOD}

\subsection{Plant material}

Roots of $C$. behen, free of diseases, were collected from local region in separate sterile bags from Bhopal, Madhya Pradesh in the month of October, 2020. Plant material (root part) selected for the study were washed thoroughly under running tap water and then were rinsed in distilled water; they were allowed to dry for some time at room temperature. Then the plant material was shade dried without any contamination for about 3 to 4 weeks. Dried plant material was ground using electronic grinder. Powdered plant material was observed for their colour, odour, taste and texture. Dried plant material was packed in air tight container and stored for phytochemical and biological studies.

\subsection{Chemical reagents}

All the chemicals used in this study were obtained from Hi Media Laboratories Pvt. Ltd. (Mumbai, India), SigmaAldrich Chemical Co. (Milwaukee, WI, USA), SD Fine-
Chem. Ltd. (Mumbai, India) and SRL Pvt. Ltd. (Mumbai, India). All the chemicals and solvent used in this study were of analytical grade.

\subsection{Bacterial strain}

The pathogenic microbes used in the current study Streptococcus mutans (MTTCC-890), Bacillus subtilis (MTCC-441), Salmonella bongori (MTCC-3858), Staphylococcus aureus (MTCC-3160), Klebsiella pneumonia (MTCC-432), Escherichia coli (MTCC-40), Aspergillus niger (MTCC- 281), Candida albicans (MTCC-183) and Aspergillus flavus (MTCC-277) were obtained from Microbial Culture collection, National Centre Forcell Science, Pune, Maharashtra, India.

\subsection{Defatting of plant material}

Shade dried powder (136 gram) of root of C. behen was extracted with petroleum ether using maceration method. The extraction was continued till the defatting of the material had taken place.

\subsection{Successive extraction with different solvents by maceration method}

Plant material were extracted in four solvents of different polarity viz water, methanol, ethyl acetate and chloroform. Powdered plant materials were extracted by maceration method. The resultant content was filtered with whatman filter paper no. 1 and kept for evaporation of solvent to get the dry concentrated extract. The dried crude concentrated extract was weighed to calculate the extractive yield then transferred to glass vials $(6 \times 2 \mathrm{~cm})$ and stored in a refrigerator $\left(4^{\circ} \mathrm{C}\right)$, till used for analysis [22].

\subsection{Maintenance of bacterial culture}

The bacterial strains were grown on nutrient agar media and inoculated at $37^{\circ} \mathrm{C}$ temperature for 24 hours and fungal strains were grown on SDA medium. Then organisms were maintained on nutrient agar slant at $4^{\circ} \mathrm{C}$ temperature and the purity of the organisms was checked at regular intervals by plating.

\subsection{Antimicrobial sensitivity}

The antimicrobial sensitivity test was employed on to the all the bacteria used under present study with ethyl acetate extract of $C$. Behen. $6 \mathrm{~mm}$ diameter wells with a stock of $100 \mathrm{mg} / \mathrm{ml}$ of each extract were used in this experiment, which were subsequently dried under aseptic circumstances. A nutrient agar plate is seeded with particular bacteria with the help of spread plate 
technique prior and left for 5 minutes. The drug impregnated filter paper discs were placed in the center of pre-inoculated culture plates then incubated for 24 hours at $37^{\circ} \mathrm{C}$. After incubation, plates were observed to see the sensitivity of extracts towards test bacteriums at particular concentration in the form of zone of inhibition.

\subsection{Well diffusion method}

The agar well diffusion method was adopted to determine the antibacterial activity of the ethyl acetate extract prepared from C. behen [23]. Firstly, microbial inoculum was swabbed over the surface of culture media. Broth cultures (undiluted) should never be used as inoculums. Then, four wells of $6 \mathrm{~mm}$ in diameter and about $2 \mathrm{~cm}$ apart were punched in the culture media containing petri plates with pre-sterilized tips. The plant extracts/standard antibiotics of different concentrations were placed on the holes. Three different concentrations of selected plant extracts $(25,50$ and $100 \mathrm{mg} / \mathrm{ml})$ were used in this test. Ciprofloxacin, ofloxacin and fluconazole were used as standard. Ofloxacin $(10 \mu \mathrm{g} / \mathrm{ml}, 20 \mu \mathrm{g} / \mathrm{ml}$, $30 \mu \mathrm{g} / \mathrm{ml}$ ) was used for Streptococcus mutans, Ciprofloxacin $(10 \mu \mathrm{g} / \mathrm{ml}, 20 \mu \mathrm{g} / \mathrm{ml}, 30 \mu \mathrm{g} / \mathrm{ml})$ was used for Staphylococcus aureus, Salmonella bongori and Escherichia coli, and fluconazole $(10 \mu \mathrm{g} / \mathrm{ml}, 20 \mu \mathrm{g} / \mathrm{ml}, 30 \mu \mathrm{g} / \mathrm{ml})$ for Candida albicans and Aspergillus niger. Subsequently, petri plates were incubated at $37^{\circ} \mathrm{C}$ for $24-48 \mathrm{hrs}$ and after incubation; they were removed and observed to see clear zones of inhibition around the well. The diameter of zones of inhibition formed around the well was measured in millimeter and their average determined.

\section{RESULTS AND DISCUSSION}

After the antimicrobial sensitivity test, out of 9 microbes, we used only 4 gram positive, gram negative bacteria and 2 fungal pathogenic microbes for antimicrobial activity of plant (Table 1). The antibacterial and antifungal activities were determined using the well diffusion method. This method is highly effective for rapidly growing microorganisms, and the activities of the test extracts are expressed by measuring the diameter of the zone of inhibition. The antimicrobial activity of ethyl acetate roots extract of $C$. Behen showed bioactivity by inhibiting growth of microbial species selected for the test as shown in table 2 and 3. The zone of inhibition shown by the extracts was comparable to the standard drug. It is effective against Streptococcus mutans, Staphylococcus aureus, Salmonella bongori, Escherichia coli, Aspergillus niger and Candida albicans in concentration dependent manner.

Table 1: Results of sensitivity of ethyl acetate extract of $C$. behen

\begin{tabular}{ccc}
\hline $\begin{array}{c}\text { Microbes } \\
\text { Codes }\end{array}$ & Microbes & $\begin{array}{c}\text { Sensitivity of } \\
\text { root extract }\end{array}$ \\
\hline Bact-1 & Streptococcus mutans & Yes \\
\hline Bact-2 & Bacillus subtilis & No \\
\hline Bact-3 & Staphylococcus aureus & Yes \\
\hline Bact-4 & Salmonella bongori & Yes \\
\hline Bact-5 & Klebsiella pneumoniae & No \\
\hline Bact-6 & Escherichia coli & Yes \\
\hline Fungus-1 & Aspergillus niger & Yes \\
\hline Fungus-2 & Candida albicans & Yes \\
\hline Fungus-3 & Aspergillus flavus & No \\
\hline
\end{tabular}

Table 2: Antimicrobial activity of standard drug against selected microbes

\begin{tabular}{ccccc}
\hline \multirow{2}{*}{ Name of drug } & \multirow{2}{*}{ Microbes } & \multicolumn{3}{c}{ Zone of inhibition } \\
\cline { 2 - 4 } Ofloxacin & Streptococcus mutans & $\mathbf{3 0} \boldsymbol{\mu g} / \mathbf{m l}$ & $\mathbf{2 0} \boldsymbol{\mu g} / \mathbf{m l}$ & $\mathbf{1 0} \boldsymbol{\mu \mathbf { g }} \mathbf{\mathbf { m l }}$ \\
\hline \multirow{2}{*}{ Ciprofloxacin } & Staphylococcus aureus & $22 \pm 2.16$ & $15 \pm 0.13$ & $12 \pm 0.15$ \\
\cline { 2 - 4 } & Salmonella bongori & $25 \pm 0.5$ & $23 \pm 0.62$ & $17 \pm 1.69$ \\
\cline { 2 - 4 } & Escherichia coli & $28 \pm 0.5$ & $21 \pm 0.57$ & $17 \pm 0.15$ \\
\hline \multirow{2}{*}{ Fluconazole } & Candida albicans & $14 \pm 0.5$ & $10 \pm 0.5$ \\
\cline { 2 - 4 } & Aspergillus niger & $14 \pm 0.5$ & $10 \pm 0.5$ & $8 \pm 0.86$ \\
\hline
\end{tabular}

Table 3: Antimicrobial activity of ethyl acetate extract of $C$. behen against selected microbes

\begin{tabular}{|c|c|c|c|}
\hline \multirow{3}{*}{ Name of microbes } & \multicolumn{3}{|c|}{ Zone of inhibition (mm) } \\
\hline & & 1 acetate ex & \\
\hline & $100 \mathrm{mg} / \mathrm{ml}$ & $50 \mathrm{mg} / \mathrm{ml}$ & $25 \mathrm{mg} / \mathrm{ml}$ \\
\hline Streptococcus mutans & $19 \pm 0.47$ & $14 \pm 0.94$ & $10 \pm 0.47$ \\
\hline Staphylococcus aureus & $18 \pm 0.47$ & $13 \pm 0.47$ & $10 \pm 0.47$ \\
\hline Salmonella bongori & $18 \pm 0.00$ & $12 \pm 0.47$ & $9 \pm 0.47$ \\
\hline Escherichia coli & $22 \pm 0.00$ & $15 \pm 0.47$ & $9 \pm 0.47$ \\
\hline Candida albicans & $18 \pm 0.47$ & $14 \pm 0.47$ & $8 \pm 0.47$ \\
\hline Aspergillus niger & $12 \pm 0.47$ & $11 \pm 0.81$ & $8 \pm 0.47$ \\
\hline
\end{tabular}




\section{CONCLUSION}

Extracts of $C$. behen in this study demonstrated a broadspectrum of antimicrobial activity against selected microbial species. The antimicrobial activity of the plant extract, possibly due to the identified phytoconstituents, further confirms its use as a health remedy in folklore medicine. Bioactive substances from this plant can therefore be employed in the formulation of antimicrobial agents for the treatment of various bacterial infections. Identification of these phytoconstituents and determination of their respective antimicrobial potencies and toxicological evaluation with the view of formulating novel chemotherapeutic agents should be the future direction for investigation. Instead of cold percolation method, soxhlet extraction, subfraction, semipure compound, or a pure compound isolated from these plants might exhibit better antimicrobial activity. Further investigations are necessary to evaluate antimycobacterial, antiviral and antiparasitic activity. Moreover, other parts of the plants need to be studied to evaluate the studied plant extracts as a potential antimicrobial agent.

\section{Conflict of interest}

None declared

\section{REFERENCES}

1. Bhatia R, Narain JP. Indian Journal of Medical Research, 2010; 132(5):482-486.

2. Boucher HW, Talbot GH, Bradley JS et al., Clinical Infectious Diseases, 2009; 48: 1-12.

3. Giamarellou H. International Journal of Antimicrobial Agents, 2010; 36:S50-S54.

4. Coates A, Hu Y, Bax R, Page C. Nature Reviews Drug Discovery, 2002; 1(11):895-910.

5. Marasini BP, Baral P, Aryal P, et al., BioMed Research International, 2015; 2015:6-12.

6. Iwu MW, Duncan AR, Okunji CO. "New antimicrobials of plant origin in. Perspectives on new crops and new uses," in Plant Breeding Reviews, J. Janick, Ed., ASHS Press, Alexandria, Virginia, 1999.
7. World Health Organization, WHO Traditional Medicine Strategy, Geneva, 2002.

8. Medina AL, Lucero ME, Holguin FO et al., Journal of Agricultural and Food Chemistry, 2005; 53(22): 8694-8698.

9. Romero CD, Chopin SF, Buck G, Martinez E, Garcia M, Bixby L. Journal of Ethnopharmacology, 2005; 99:253-257.

10. Duraipandiyan V, Ayyanar M, Ignacimuthu S. BMC Complementary and Alternative Medicine, 2006;6:23-70.

11. Djeussi DE, Noumedem JAK, Seukep JA. et al., BMC Complementary and Alternative Medicine, 2013; 13: 20-30.

12. Khare CP. Indian medicinal plants, 2007; pP 36. Springer.

13. Khare CP. Indian Herbal Remedies: Rational Western Therapy, Ayurvedic and Other Traditional Usage, Botany, 2004; pp 137-138. Springer.

14. Mirza M, Najafpour NM, Dini M. Chemical composition of the essential oil of Centaurea behen. Iranian Journal of Aromatic and Medicinal Plants, 2003; 19:227-232.

15. Scott TL. Invasive Plant Medicine: the Ecological benefits and healing abilities of invasives, 2010; pp 232. Healing art press, Rochester.

16. Afzal S, Afzal N, Awan MR, Khan TS, Gilani A, Khanum R, Tariq S. Journal of Ayub Medical College, 2009; 21:52-57.

17. Abivardi C. Iranian entomology: An Introduction. 2001; pp 520. Springer, Berlin.

18. Rustaiyan A, Niknejad A, Zdero C, Bohlman F. Journal of Phytochemistry, 1981; 20:2427-2429.

19. Esmaeili A, Elham K. Journal of Paramedical Sciences, 2012; 3:8-11.

20. Mahdi M, Navaei NM, Dini M. Iranian Journal of Medicinal and Aromatic Plants, 2003; 19:227-32.

21. Bhargava PN, Dutt S. Proceedings of the Indian Academy of Sciences, 1944; 19:163-166.

22. Mukherjee PK. Quality control of herbal drugs. $2^{\text {nd }}$ Ed. Business Horizons; 2007; 34-70.

23. Bauer AW, Kirby WMM, Sherris JC, Turck M. American Journal of Clinical Pathology, 1966; 45:493496. 